\title{
Joint Determinants of Monetary, Macroeconomic, Social and Income Inequality
}

\author{
Abdulrahman Taresh A.1), Dyah Wulan Sari' ${ }^{2}$, Rudi Purwono ${ }^{3)}$ \\ ${ }^{1}$ Faculty of Economic and Business, Airlangga University \\ Corresponding Author: dyah-wulansari@feb.unair.ac.id
}

Received: March 2020 | Revised: June 2020 | Accepted: July 2020

\begin{abstract}
This study discusses all the potential relationships between monetary, macroeconomic, social and income inequality in an integrated manner by making Indonesia a concrete case study. This empirical study discussed the relationship based on theoretical modelling and carried out through appropriate estimators applied to the data of 33 provinces in Indonesia. To achieve this objective, the simultaneous model of seemingly unrelated regressions (SUR) was used. The results concluded that there are variables that jointly determined the monetary, macroeconomic and social also income inequality. Like, consumption can increase inflation and macroeconomic while at the same time can reduce population growth and human development, and increases income inequality. Savings which determine credit also pushes macroeconomics while simultaneously increasing population growth, and it can reduce income inequality. Minimum wages can reduce inflation and encourage production growth, while increases human development and reduces population growth also can reduce income inequality. Unemployment can also reduce inflation and increase economic growth, at the same time reduces population growth and human development while increases income inequality. Education and health encourages economic growth and the level of human development then can reduce income inequality.
\end{abstract}

Keywords: Monetary; Macroeconomic; Social; Income Inequality; SUR Model JEL classification: E50, O11, O15, D63

How to Cite: A Taresh A., Sari D. W., Purwono R. (2020). Joint Determinants of Moneraty, Macroeconomic, Social and Income Inewuality. Jurnal Ekonomi Pembangunan: Kajian Masalah Ekonomi dan Pembangunan, 20(2). 134-160. doi:https://doi.org/10.23917/jep.v21i2.11254

DOI: https://doi.org/10.23917/jep.v21i2.11254

\section{Introduction}

The joint achievement of economic and social development is desirable in a country. The monetary and macroeconomic policies are a means of instruments to encourage social development and redistribute income. On the other hand, the distribution policy for the attainment of social welfare promotes the growth and stability of the economy. Therefore, knowing the interrelationship between monetary, macro, social, and income inequality variables are considered important when making policies on the social economy. However, these interrelationships are discussed separately in previous studies, especially in developing countries such as Indonesia, which has a large population, as the world's fourth country in population size, it suffers from relative weaknesses in human development and has a high in income inequality, despite achieving high gross domestic product (GDP) so that it is 
Jurnal Ekonomi Pembangunan: Kajian Masalah Ekonomi dan Pembangunan, 21 (2), 2020, 134-160

included in the world's 20 largest economies. Where Indonesia's Gini index is on average 0.40 during the period 2005-2018.

Therefore increasing income inequality has been the policy objective of the Indonesian government in recent times to reduce income inequality through human development. In 2018, Indonesia's human development index has risen to 0.713 . The role of government spending policy to improve human development, education and health in economic growth and reducing income inequality is considered important in economic policy. However, there are monetary policies that were overlooked by the policies, and previous research must be given priority when achieving welfare and equitable distribution.

Domestic credit is a priority for monetary policy and is determined by the central bank to achieve the desired level of economic growth. In another sense, it is a framework that includes regulations for lending and banking facilities, which aim to prioritize investment, then can achieving the required level of human development and income distribution. At the same time, credit is a risk factor that can affect a country in an economic crisis that affects the economy as a whole. During the Southeast Asian crisis, domestic credit was a factor in reducing Indonesia's ability to get rid of the crisis, this has spread the phenomenon of unpaid loans. Overall liquidity surpluses were used in Indonesian sovereign bonds due to delays in the outcome of domestic credit in the event of the impact of the expansion in fund hiring. This has increased inflation due to expansionary monetary policy. Inflation worsens the distribution of income due to increase income of the rich and reducing the income of the middle class and the poor ( $\mathrm{Li}$ and Zou 2002)

Therefore, this study analyzes the interrelationships between monetary, macroeconomic, social, and income inequality in an integrated manner and identifies the variables that jointly determine them, as to make Indonesia a concrete case study. Empirically discussing this relationship is based on theoretical modelling and carried out through an appropriate estimator applied to the data of 33 provinces in Indonesia. In this study, we will investigate components of the linkages and joint determination of monetary and macroeconomic policies and social development. To achieve this goal, will use seemingly unrelated regressions (SUR), it will estimate multiple structural equations with an error component in which monetary variables determine macro and social variables, and affect income inequality. Then the income inequality determines the social and macroeconomic, which then influence the monetary variables. Meanwhile, variables of consumption, savings, wages and unemployment, urbanisation, education and health which are the joint determination.

This study examines the overlap between economic and social variables to have important implications for policymaking aimed at promoting economic growth that is equitable and that achieves the fairness of the community fairly. Through this study, we look forward to the joint development of economic and social structures as the main mechanism for achieving goals in terms of efficiency and equality. In a sense, to what extent and through which components, the monetary and macroeconomic policies produce an exchange between economic growth and social development. There are no previous studies covering this issue integrally, therefore it is interesting to discuss the determination and linkages between monetary, macroeconomic, social and income inequality in Indonesia with an overview of the literature. The first link we will discuss the relationship between the monetary, macroeconomic, social and income inequality, then discussed the variables that jointly determine it, as illustrating these links by Figure 1. 


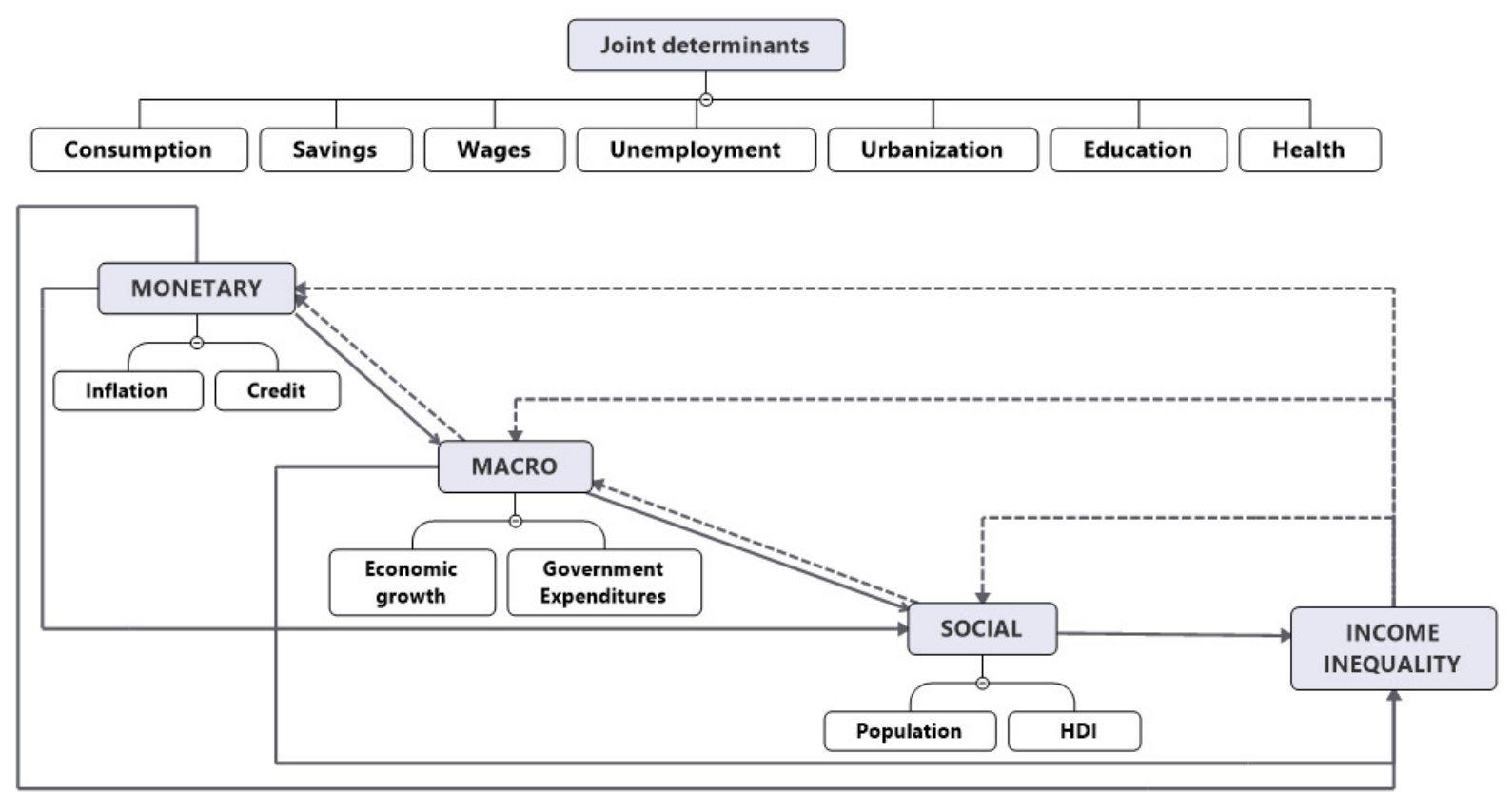

Figure 1. An illustration of a joint determination for monetary, macroeconomic, social and income inequality

Notes: $(\longrightarrow$ ) indicates the initial direction of the direct and indirect relationship from monetary to income inequality. (4----) indicates inverse that relationship from income inequality to monetary.

1.1 The relationship between monetary, macroeconomic, social variables and income inequality

a) Relationship between monetary and macroeconomic

Credit plays an important role in the economy because expanding lending increases the volume of production capacity, it increases production and improves operations by investing funds borrowed in high-yield production projects. Credit is the most important way for banks to invest their financial resources and to keep banks active. Repayments from loans are a large part of the credit process for expanding economic activity by achieving various objectives. The purpose of the loan is to increase production in terms of quantity and quality and to work to increase tariffs so as to achieve growth and economic stability, so that access to production surpluses, then add to exports and reduce imports, and thereby increase state income from taxes. Tinoco-Zermeno, et al. (2014) show that the availability of credit in the economy has a positive impact on gross domestic product. In contrast Peia and Roszbach (2015) show that there is an inverse causality between bank credit and economic growth.

Then as found by Gashe (2017), that a significant and positive two-way relationship between economic growth and inflation. And as found by Aydın, Esen et al. (2016), inflation will have a positive effect on economic growth if the inflation rate does not exceed the level of 7.97\%. And also Khan and Naushad (2020) noted that inflation below 3 to 7 per cent is beneficial for economic growth in the world while higher inflation is dangerous for world economic growth. Inflation stimulates economic growth, meaning that a decrease in the general price level at a low level does not reflect a good indicator, because it reduces incentives to expand production. Thus at the general price level at low levels signs of recession will reappear in the economy. Thus this effect when it occurs will create a bumper against inflation from one side and will increase credit and investment banking from the other side. In this case, an increase in government spending will play an oppressive role in credit policy. The government wants to revive economic energy by 
Jurnal Ekonomi Pembangunan: Kajian Masalah Ekonomi dan Pembangunan, 21 (2), 2020, 134-160

injecting credit with more government funds. There is a lot of empirical evidence that rejects Keynesian and neoclassical theories which are considered that increasing government spending raises interest rates, thereby reducing private sector spending and investment, for example; Murphy andWalsh (2018), Miranda-Pinto, Murphy et al. (2020) and Auerbach, Gorodnichenko et al. (2020) who support the idea that government spending tightens credit markets, they are shown that government spending can slacken the credit market by redistributing income to savers.

Inflation as a result mainly from fiscal expansion in public spending and an increase in the budget for public consumption. According to Gumata and Ndou (2017), government spending acts as a channel for positive inflation shocks in the high inflation system and reinforces negative effects on economic growth. Gumata and Ndou (2017) show that at all inflation rates below 6 per cent, government spending plays a positive role in spreading the effect of low inflation on economic growth, and is different with the negative effect when inflation is above 6 per cent. Nguyen (2019) investigated the long-term and short-term effects of government spending on inflation in three developing countries in Asia, India, China and Indonesia, the results confirm there are a cointegration and causal relationship between government spending and inflation in these countries, and it was found that Government spending has a positive impact on inflation in Indonesia and India. Mehrara, Soufiani et al. (2016) shows the nonlinear relationship between inflation and government spending, in the case of high liquidity growth the government spending is inflation, in the sense of a high liquidity growth regime, the government expenditure variables have a high inflationary impact and may not stimulate economic growth.

b) The relationship between monetary, social and income inequality

Monetary variables that have influence with macroeconomic variables, at the same time affect social variables. Based on the theory of the
Jones production function, namely the increase in population caused by the production function for consumer goods and the production function for children. Jones (1997) assumes that birth rates depend on people's preferences to have children compared to consuming the goods. It is assumed that inflation and high loan interest increase the cost of having children according to the family, thereby reducing population growth. Then the credit increases investment in human resources, according to Lochner and Monge-Naranjo (2002) the policies aimed at increasing investment in human resources should be increased the number of credit lenders because individuals will optimally choose to invest more in their human resources, so increase their income capacity in the future, thus, a broader loan program must go hand in hand with an increase in subsidies for education. The same is true for Lochner and Monge-Naranjo (2012), Heckman and Mosso (2014) and Hai and Heckman (2017), who find evidence that credit constraints affect human capital accumulation. However high inflation degrades human development because rising prices for basic services and commodities will reduce the level of people's welfare. The study of Hassan, Khalid et al. (2016) one empirical which shows that inflation increase poverty and decrease human development.

Inflation and credit at the same time affect income inequality. High inflation will cause a decline in income distribution, according to Albanesi (2007), that inflation and income inequality are positively related, and low-income families are more vulnerable to inflation because households with low incomes are mostly more to consume income. As found by Al-Marhubi (1997) and Cysne, Maldonado et al. (2005) that countries with higher levels of inequality have higher average inflation. Also Yolanda (2017) found that the effect of inflation on poverty was significant and positive. Gonzales and Rojas-Hosse (2019) show that inflation shocks substantially affect countries that experience higher levels of income inequality, thereby suggesting that the adverse effects of inflation are exacerbated by high levels 
Jurnal Ekonomi Pembangunan: Kajian Masalah Ekonomi dan Pembangunan, 21 (2), 2020, 134-160

of income inequality. Then an increase in credit will reduce income inequality. The suppression of credit, banking sector performance barriers tend to increase income inequality, as indicated by Johansson and Wang (2014) and Ghossoub and Reed (2017). According to the model of Dinopoulos, Unel et al. (2018), if workers are more productive at higher levels of firm output, the lower credit supply increases the intensity of company capital and increases income inequality by increasing relative capital leases compared to wages, and it has an ambiguous effect on welfare.

On the other hand, income Inequality can reduce inflation and increase credit because a large part of the income of the poor is for consumption while a large portion of the income of the rich to save, as considered by Chan, Dang et al. (2016) and Chu and Wen (2017), income inequality contributes to increasing the savings of the rich and reducing the consumption of the poor. According to Stockhammer (2015), income inequality leads to speculation in credit and increases leverage among richer households, because inequality spends their consumption opportunities. In accordance with the by Malinen (2016), that higher income inequality leads to higher bank credit in the long run.

c) The relationship between macroeconomic, social and income inequality

There are empirical studies that provide evidence supporting the proposition that higher population growth can increase economic growth. For example, Miri and Maddah (2018), who examined the effect of population structure on economic growth in Iran, the results show that the effect of population growth aged 15-64 years of the total population is positive and significant on economic growth, in the short and long term. Instead, there are empirical studies that provide evidence that does not support the proposition that higher population growth can increase economic growth, for example, Sinding (2009) and Ashraf, Weil et al. (2013) concluded that lower population growth in developing countries will significantly increase per capita income and that the reduction in births should be a policy objective for most developing countries. Karra, Canning et al. (2017) shows that there is a significant negative correlation between population growth and economic growth in Africa. Also Bucci and Raurich (2017) explain why in the long run correlating economic growth with population growth may ultimately be negative when research and development and human capital investment are tools that drive economic growth.

Human development increases the quality of work and the quantity of production. Many existing studies show that human development plays an important role in the relationship between resource development activities and economic growth, through a combination of conceptual and mathematical models. For example, the study of Ulas and Keskin (2017) aims to compare the economic performance of 20 countries in the period 2010-2014, to understand the effect of the human development index on economic performance, the results show that there is a positive correlation between the human development index and economic performance. Also the results of Saputri and Woyanti (2014) show that human capital has a positive relationship with economic growth and vice versa.

Population growth will increase income inequality due to low living standards at high population levels, as Malthus considers, assuming that an increasing population will increase the proportion of poverty. As well as, Lee (2001) considered that the high population growth rates have a direct role in national income inequality. However, increasing the quality of the population through human development will reduce income inequality. Human development increases the level of income and wages which will reduce income inequality. The concept of endogenous growth theory by Romer (1986) and Lucas Jr (1988) suggests a positive correlation between human resource development activities and income. Empirical Study of Castells $\square$ Quintana, Royuela et al. (2019) analyzed the relationship between income inequality and the human development index and its components in a panel of data for 
Jurnal Ekonomi Pembangunan: Kajian Masalah Ekonomi dan Pembangunan, 21 (2), 2020, 134-160

117 countries, during the period 1970 to 2010, and found evidence that there was a negative long-term relationship between inequality and human development.

Then, income inequality increases population growth, because low-income segments are more likely to choose the quantity of children, unlike the rich who are more inclined to choose the quality of having children than quantity. According to Leibenstein (1963) the benefits of additional children decrease when family income increases, which is the reason why low-income families want to have more children. Leibenstein concluded that there was an inverse relationship between family income and birth. Increasing income inequality also causes a low level of population welfare, and worsens education and health levels, thereby reducing the human development index. Yang and Qiu (2016) found that poor families participate in investment in human resources, especially education, compared to people with high income. Thiel (2016)found evidence for the negative effects of long-term and short-term income inequality on the human development index and education outcomes in panel data for 117 countries over the period 1970 to 2010 , and detected that these impacts on human development were negatively dependent at the prevailing level of inequality. So that high-income inequality can reduce economic growth. Empirical studies conducted by Gu, Tam et al. (2018), shows that income inequality is a consumption variable and that the way in which inequality develops has negative consequences on economic growth. An empirical study also, Rodionov, Kudryavtseva et al. (2018) found that a high human development index and a low Gini index had a positive impact on gross regional products in 68 regions of the Russian Federation during the period 2000-2014. In contrast, Brida, Carrera et al. (2020), examining Granger's causal relationship between economic growth and income inequality, for two samples, namely 38 countries between 1980 and 2015, and 23 countries during the 1980-2010 period, the results show that in developing countries economic growth was improved with income inequality. As well as, Ghosh (2020) shows that there is a twoway causality relationship from the transmission of income inequality to the volatility of economic growth in ASEAN-5 countries. The most rational opinion of Nguyen, Le et al. (2020) who argue that concentrating on poverty alleviation and income inequality will help to develop a more equitable society without sacrificing economic growth. Thus increasing the level of income inequality will also increase the desire for government spending to overcome the problem of high-income inequality, so that it will increase government spending on income redistribution. According to Tanninen (1999), in accordance with the fiscal policy approach, a high level of income inequality leads to higher demand for redistribution.

On the other hand, macroeconomics, namely economic growth and government spending, influences population growth and the level of human development. An increase in income would reduce population growth as perceived by Nelson (1956). According to Jones (2020) now in high-income countries become births below the substitution level, on average women have less than two children. In contrast, Sufiyan, Jummai et al. (2020) found in Nigeria, as economic growth advanced, population numbers also increased in urban areas. Then government spending negatively affects population growth, governments in countries with high populations have the desire to reduce population growth with a policy of raising the marginal cost of children.

At the same time, macroeconomics increases the level of human development, because the increasing output will increase the level of welfare. Government spending also focuses on investment in human resources. Olofin (2020) shows that human capital has a positive and significant relation with output in African countries, but when human capital interacts with government spending a negative relationship is found. Bhowmik (2019) found that a one per cent increase in GDP per year caused a significant increase in the $0.105 \square$ human development index per year in ASEAN countries. These results may not be discovered by chance in the sense that all 
countries studied are documented among corrupt countries. Most of the funds intended to increase human capital may not be spent on the intended purpose.

According to Nguyen, Le et al. (2020), the determinants of reducing income inequality and poverty include investment in human capital and the growth rate of gross domestic product. So that macroeconomics can be considered to reduce income inequality by increasing human development and improving living standards, and by focusing government spending on subsidies and increasing the incomes of the poor. Instead Lise, Sudo et al. (2014), it was found that income inequality increased substantially as income increased. Also empirical study of Rubin and Segal (2015) concluded that the link between economic growth and income inequality was positive. Aremo and Abiodun (2020) and Koh, Lee et al. (2020), find a unidirectional causal relationship running from economic growth to income inequality for middle-income countries in Sub-Saharan Africa and China. Akinyemi, Magareth et al. (2019) and Baker, Hone et al. (2019) agreeing that government expenditure will reduce income inequality if government expenditure aims to increase access to quality health facilities and educational opportunities by increasing employment creation opportunities.

\subsection{Joint determination of monetary, macroeconomic, social and income inequality}

a) Joint determination of monetary

Consumption, savings, wages and unemployment are common determinants of monetary variables. When consumption rises the price will rise then credit will decrease. Overall household consumption increases inflation. As an empirical study by Nagayasu (2017), the importance of supply and demand factors in explaining regional inflation, and finding evidence that different service consumption patterns across regions explain regional inflation in Japan. As also Han and Mulligan (2008), found a substantial relationship between public consumption and inflation for 80 countries during the period 1973 to 1990 . While saving is a determinant of credit, saving increases credit. Savings can also affect consumption offspring, thereby reducing inflation. The increases in savings reduce the cost of loan interest, thereby reducing the cost of production and then the price of goods and services is reduced. Taye (2017) found a causal relationship between national saving and inflation in Ethiopia. Also Gashe (2017) found inflation is negatively affected by savings. This effect occurs when the state of a tight credit policy causes underestimation of inflation (Van Wijnbergen 1983).

High wages and low unemployment affect credit positively while at the same time increasing inflation due to higher production costs. According to Neumark (2019), the credit will increase by changing part of the increase in the minimum wage into savings by the workforce. Cooper, Luengo $\square$ Prado et al. (2020) found that with increases in minimum wages, prices and expenses followed up, and also increases in minimum wages were associated with a reduction in total debt among households with low credit scores, higher car debt, and increased access to credit. Dromel, Kolakez et al. (2010) assumed that wages are exogenous and workers lend their savings to representative banks. Ball and Mazumder (2019) found that high unemployment during the Greatest Recession in the US did not reduce inflation much, and explained the reason for partly because inflation expectations were anchored, and partly because short-term unemployment rose less sharply than total unemployment. Also, Bölükbaş (2018) found that there is a statistically significant and negative two-way causal relationship between unemployment and inflation for 20 developing countries including Indonesia.

Urbanization also explains the monetary variable by increasing inflation and bank credit. Goldstone (1984) has constructed a simple model for the impact of urbanization on monetary 
Jurnal Ekonomi Pembangunan: Kajian Masalah Ekonomi dan Pembangunan, 21 (2), 2020, 134-160

circulation, arguing that taking into account the effect of urbanization and specialization of work on the speed of money provides a more complete understanding of the price revolution in the United Kingdom, the implications are taken to account for inflation in early modern Europe and the world developing contemporary. Chinonso and Justice (2016) found that inflation in urban areas is higher than in rural areas in Nigeria. Then according to Gabriel and Rosenthal (2013), urbanization agglomeration increases access to skilled workers and information, both of which must increase liquidity for credit. Carmignani, De Blasio et al. (2019) investigating whether companies have better access to bank credit in areas with greater urbanization rates, the results show that urbanization affects access to credit is positive for the company.

b) Joint determination of macroeconomic

Consumption and savings are general determinants of macroeconomic (economic growth and government expenditure). Consumption and savings by increasing output, while increasing government spending. According to Cameron (1978), the expansion of the public economy is influenced by the greater economic prosperity of a country. Then according to Diacon and Maha (2015), the effect of consumption on output is stronger for low- and middle-income countries, a logical conclusion because high-income countries allocate more capital for investment and are highly specialized in research and development activities. Gashe (2017) has found a positive and significant effect of consumption on economic growth, and also found a positive causal relationship between domestic saving and economic growth. National savings can promote output. Empirical evidence also from Patra, Murthy et al. (2017) shows that saving drives real activity and output growth. As well as, Gu and Tam (2013) providing an explanation for the complex problem of Chinese savings found that output growth was positively influenced by savings. Shonchoy (2010) found evidence from Wagner's law which states that people's demand for government services is income-elastic.

High minimum wages and low unemployment contribute to economic growth. At the same time, the phenomenon of unemployment and low wages increases government spending for the purpose of overcoming the problem. Cahuc and Michel (1996) show that minimum wages can have a positive effect on growth by encouraging more accumulation of human capital. According to Carter (1998), minimum wages that increase employment will increase output but clearly reduce labour force participation and hurt those who remain unemployed. Study of Chu and Wen (2017) show that the negative effect of minimum wage heights on growth occurs when labour intensity of skills is low in production. Askenazy (2003) states that minimum wages shift efforts from production to research and development, thus accelerating long-term economic growth. Unemployment has been seen as an economic problem that wastes a country's labour resources and results in the loss of welfare in terms of lower output. According to Anghel, Anghelache et al. (2017), unemployment has a negative effect on output through the percentage of labour resources that cannot be used to increase the production of goods and services. Abraham and Nosa (2018) found a negative relationship between the unemployment rate and the GDP growth in a special study of middle and upperincome countries in Sub-Saharan Africa and showed that the more people there were workers there would be an increase in output growth. Also, Adelowokan, Maku et al. (2019) show that unemployment has a negative and significant relationship with economic growth in Nigeria. Then according to Pissarides (1983), in some cases, optimal government spending may require subsidies for low-wage jobs. Ono (2017) also found that low capital growth rates created a positive correlation between unemployment and government spending.

The growth of urbanization will increase economic growth because there is a connection with the scale of the production economy and diversification of economic activities and the 
transformation from the agricultural community to the industrial society. Many studies have analyzed available data to establish the role of urbanization growth on economic growth. For example, Sarker, Khan et al. (2016) using the vector error correction model, shows that there is a long-term causal relationship running from urban population growth to economic growth in South Asia. Bettencourt (2020) shows that in larger urban areas, manifests higher per capita income because of the effects of agglomeration. Then, urbanization growth can influence government expenditure. Ubogue (1983) assumed that the rate of urbanization causes high per capita costs for government goods and services.

Education and health also common determinants for macroeconomic. Education and health improve work quality and production. With deteriorating health and the spread of health complaints will weak educational structures, the government is working to tackle that problem by increasing spending. Better health and education tend to be in various ways to promote economic growth. According to Barro (2013) that education, work experience, and improved health increase worker productivity, and the improving health decreases mortality and disease and thus decreases the effective depreciation rate on human capital; namely about education and health, thus improving education and health will increase demand for human resources and thus has a positive effect on productivity. Aslan, Menegaki et al. (2016) show that there is a causal relationship from health and the total number of tertiary education students to GDP in seven industrialized countries from 1980-2009. Also, Sharma (2018) shows evidence from 17 developed countries that population health and education that are proxied by going to school have a positive and significant effect on economic growth. Ghiasi, Sarlak et al. (2019) it was also found that indicators of human health and education spending had a significant positive effect on economic growth in the Iranian province. Education increases the productivity and creativity of people and promotes entrepreneurship and technological progress, besides it plays a very important role in securing economic and social progress and increasing income distribution Mahajan (2020). The good health has a positive and sizable effect on aggregate output, even when controlling for workforce experience, and the health effect in growth regression seems to be a real labour productivity effect. Neofytidou and Fountas (2020), using a balanced panel of 19 industrial economies and a long time series from 1950 to 2013, concluded that health must be considered as an important element of the economic performance.

\section{c) Joint determination of social variables}

The human development index, which reflects the combined achievements of society in education, health and living standards, has since been introduced as the most well-known indicator of the level of social development. There are several opinions that are proven that saving and consumption affect the index of human development, through linking welfare, and sustainable development with wealth and the environment. Neumayer (2001) proposes that a country's human development is potentially unsustainable if the net consumption of manufactured and natural capital stock is greater than its investment. This assumption does not contradict the results of the Gnègnè (2009) that conducted in 36 developing and selected developed countries, indicate there is a positive and significant relationship between net savings and aggregate welfare as measured by infant mortality and human development index. Also, Chen, Ma et al. (2010) have used the human development index as a process for the level of social development, and show that there is a significant U-shaped relationship between natural resource consumption per person and the level of social development, based on a dataset of 136 countries. Then, based on the theory of the production function for Jones (1997), that birth rates depend on people's preferences to have children over consuming the goods, assuming that consumption also reduces population growth. Savings also 
Jurnal Ekonomi Pembangunan: Kajian Masalah Ekonomi dan Pembangunan, 21 (2), 2020, 134-160

reduce population growth while increasing the level of welfare and human development. Savings reduce the incentive to have children and fertility will be lower. Boldrin and Jones (2002), Puhakka and Viren (2012) and Matchaya, Nhemachena et al. (2018) found empirical evidence for the idea that there is a negative relationship between savings and fertility.

Increasing wages and low unemployment reduces population growth and increases the level of welfare and human development. Cahuc and Michel (1996) considered that high minimum wages increase the welfare of human capital, because, low demand for unskilled labour, caused by minimum wages, can create incentives for workers to accumulate human capital. Escudero and Pérez Castroviejo (2010) provide evidence that there is a relationship between wage increases and the human development index in Biscay. Widodo, Irawan et al. (2019) show that minimum wages have a positive and significant influence on the human development index in five selected provinces in Indonesia.

Unemployment has been categorized as one of the obstacles to social progress, and leads to lower incomes and poor living standards, thereby causing loss of human welfare. According to Suleiman, Kassim et al. (2017), unemployment is a major obstacle to social progress and results in a waste of trained workforce. Akinbobola and Saibu (2004) found that low unemployment increases human development and consequently reduces poverty in Nigeria. Bhowmik (2019)found that a one per cent increase in the unemployment rate per year caused a significant decrease of $0.027 \%$ in the annual human development index in the ASEAN economy. Also, Feriyanto (2016) show that the employment variable has a positive and significant impact on the human development index in Indonesia. Then an increase in the minimum wage will result in reduced birth rates [Bullinger (2017); Kreyenfeld and Andersson (2013); Del Boca and Sauer (2009); Apps and Rees (2004)]. In addition to the effects of wages, unemployment can be positively related to women's fertility decisions, because reducing the cost of having children easily provides additional time for childbearing and child care. According to previous refutations; (Budig 2003), Haan and Wrohlich (2011), and Andersen and Ozcan (2011), and Aksoy (2016), that women's work and labour participation reduce fertility, their results show that full-time employment women and employment rates at the country level reduce expected fertility, and children still need to invest time primarily.

Urbanization is considered as one of the main dimensions of the socio-economic development process, which is a necessary condition for economic development because economies of scale and agglomeration in urban areas enable economic development through industrialization so that urbanization increases the level of human development. study of Tripathi (2019) provides evidence that developing countries need to promote balanced urbanization with improved basic urban services to improve the ranking of the human development index, and the study found overall percentages of urban populations to have a positive effect on the value of the index of human development, and suggest that the measures of percentage urban populations are the most important than of all other urbanization measures. There are also empirical studies such as, Bhattacharya (1998) and Anisujjaman (2015) who finds the fact that the rate of urbanization is positively related to the level of the human development index. Then, urbanization reduces population growth because urban communities prefer to improve the quality of children rather than the quantity of children such as in rural communities. In the opinion of Marx (1818-1883) that population evolution and overpopulation differ between societies, depending on the factors that affect those who depend on agricultural production. Flückiger and Ludwig (2017) show that the process of urbanization is associated with a fertility transition and increased investment in children's education in Sub-Saharan Africa. However, urbanization is referred to as a process 
in which more and more populations live in cities and suburbs (Sengupta and Ghosha 2008).

Education and health are another determining human development and population growth. High levels of public health and education will lead to promoting human development. Razmi, Abbasian et al. (2012) found that there is a positive and significant relationship between health and the human development index in Iran. Widodo, Irawan et al. (2019) also found that government spending on education and health has a positive effect on the human development index in five selected provinces in Indonesia. Also, Bhowmik (2019) found that a one per cent increase in education and health spending per year caused a significant increase of $0.028 \%$ and $0.0124 \%$ in the annual human development index in ASEAN countries. Education is associated with lower mortality, better health and different migration patterns. The authors found that women's education and child mortality were the most important factors explaining differences in fertility across the country, and low levels of child preference contributed to lower births (Drèze and Murthi 2001). According to Lutz and Samir (2011) and Lutz and KC (2013), universally almost all women with higher levels of education have fewer children, through choices and higher access to birth control. Varvarigos and Arsenis (2015) provide evidence that the effect of public education expenditure will be a decrease in the rate of population growth at a later stage of development.

\section{d) Joint determination of income inequality}

Consumption and savings can determine income inequality. Increased consumption, especially non-food consumption, increases income inequality because non-food consumption not only comes from higher incomes but also from lower incomes. According to Charles and Lundy (2013), the consumers imitate those at the top of their local economic ladder through large expenditures in the category of highly visible goods such as jewellery, clothing, vehicles and entertainment. These commodities are monopolizing their production by big capitalists, so an excess in increasing non-food consumption will increase income inequality. Then national savings can promote income inequality, as found by Gu and Tam (2013) and Gu, Tam et al. (2018), the income inequality was positively influenced by savings.

Then, the high minimum wages and low unemployment can reduce income inequality. According to Neumark (2019), the increase in the minimum wage is likely to remain attractive as a policy response to deal with low employment, poverty and income inequality that is constantly increasing. The study of Bird and Manning (2008) show that minimum wages are an effective antipoverty instrument in developing countries such as Indonesia because a higher share of the cost of increasing minimum wages is paid by the rich, the study also found increases in minimum wages increased net income for $21 \%$ of households in Indonesia. As well as, Brito and Kerstenetzky (2019) found that the minimum wage contributed to a decrease of $38.2 \%$ in the proportion of poor people, and $39.4 \%$ in the intensity of poverty and $40.6 \%$ reduction in the severity of poverty. Then an increase in unemployment will increase income inequality, as found by Cysne and Turchick (2012) $i$ that income inequality is positively correlated with unemployment if the unemployment rate and the Gini coefficient are greater than $15 \%$ and $28 \%$ respectively.

Urbanization determines income inequality as Kuznets (1955) assumed that in an advanced stage of growth, people move to urban areas, working in the industrial sector, thereby increasing their wages. However, according to Siddique, Wibowo et al. (2014), if rural communities move to urban areas with little or no education and skills that are in line with the demands of the workings of the city company, then these people may be unemployed or may have to be involved in jobs with much lower wages, thus 
Jurnal Ekonomi Pembangunan: Kajian Masalah Ekonomi dan Pembangunan, 21 (2), 2020, 134-160

worsening wage inequality. While some studies argue that urbanization exacerbates income inequality. Sulemana, Nketiah-Amponsah et al. (2019) examined whether urbanization correlates with income inequality, using unbalanced panel data for 48 Sub-Saharan African countries to find evidence of a positive relationship between urbanization and income inequality in the region. According to Qiu and Zhao (2019) income inequality is higher in exclusive cities because skilled workers are relatively rare in exclusive cities that can enjoy higher skill premiums.

Education and health variables that reduce income inequality. Low education and lack of educational opportunities for the poor will increase income inequality. Marks (2015) discusses the relationship between income and education, concluding that education influences family income. Yang and Qiu (2016) found that family investment in education plays an important role in explaining income inequality and intergenerational income mobility. The level of education also can increase the quality of the work ladder so that it can reduce income inequality. Health also determinant income inequality. Poor health and the spread of disease increase income inequality. Pickett and Wilkinson (2015) found that there is a causal relationship between income inequality and health. Also, the results of Detollenaere, Desmarest et al. (2018) confirm that primarily the structural dimensions and continuity of primary care strength can buffer inverse associations between income and health inequality in Europe.

\section{Research Method}

\subsection{Data types and sources}

This paper discusses all potential links between income inequality, monetary, macroeconomic and social variables in an integrated manner. After correlating it simultaneously, we will determine the variables that jointly affect it. Therefore to achieve this goal will use the simultaneous model of seemingly unrelated regressions (SUR).
The data used were obtained from the central bank of Indonesia and Bank Indonesia. According to the available data, has selected the most period for that available data, which is longitudinal panel data for the period 2005 to 2018. The data covers 33 provinces in Indonesia, that includes all provinces except for the most recent one (North Kalimantan) for which its data not available. Therefore this study has a higher number of observations and degrees of freedom which amount to 462 . Table 1 presents the descriptive statistics of each variable. Estimating the joint determination of monetary, macroeconomic, social and income inequality variables, this study model includes fourteen variables. Namely, the income inequality variable which is the provincial Gini ratio. Macroeconomic variables are, a domestic product which is an indicator of gross regional domestic product and government expenditure is a recapitulation of the realization of district/city government expenditure. Monetary variables are loans which represent the amount of loans given by rupiahs of commercial banks and rural banks according to the location of the provincial project and inflation as measured by the consumer price index by province. Social variables are population variables which are population growth of the province and human development are human development index by province.

The variables that jointly determine the above variables are consumption variables which are the average monthly per capita expenditure in urban and rural areas by province and nonfood items group, savings are the position of public rupiah deposits in commercial banks and rural banks by province, and wage variable which is the regional/provincial minimum wage, and unemployment, namely the open unemployment rate by province. There is also an urbanization variable which is the number of urban subdistricts by province, and the health variable is the percentage of the population that has health complaints in the past month (per cent), and the education variable which is the pure participation rate of high school. 
Avalaible online at http://journals.ums.ac.id, Permalink/DOI: 10.23917/jep.v21i2.11254

Jurnal Ekonomi Pembangunan: Kajian Masalah Ekonomi dan Pembangunan, 21 (2), 2020, 134-160

Table 1. Descriptive statistics of variables

\begin{tabular}{|l|c|c|c|c|c|}
\hline \multicolumn{1}{|c|}{ Variables } & Mean & Std. Dev. & Minimum & Maximum & Data source \\
\hline Inflation (Consumer Price Index) & 0.05 & 0.24 & -0.47 & 1.27 & Central Bank of Indonesia \\
\hline Domestic Credit & 0.03 & 0.86 & -2.08 & 2.45 & Central Bank of Indonesia \\
\hline Gross Regional Domestic Product & -4.66 & 1.00 & -2.23 & 2.29 & Statistics Indonesia \\
\hline Government Expenditures & 9.32 & 1.00 & -2.32 & 2.55 & Statistics Indonesia \\
\hline Population growth & 2.06 & 1.64 & 0.26 & 6.36 & Statistics Indonesia \\
\hline Human Development Index & 1.85 & 0.02 & 1.76 & 1.90 & Statistics Indonesia \\
\hline Income Inequality (Gini Index) & 0.34 & 0.04 & 0.24 & 0.46 & Statistics Indonesia \\
\hline Consumption & 0.00 & 0.99 & -2.50 & 3.02 & Statistics Indonesia \\
\hline Domestic Savings & 0.02 & 0.90 & -2.29 & 2.85 & Central Bank of Indonesia \\
\hline Minimum wage & 4.37 & 0.35 & 3.45 & 5.32 & Statistics Indonesia \\
\hline Unemployment Rate & 6.01 & 0.20 & 5.53 & 6.52 & Central Bank of Indonesia \\
\hline Urbanization Growth & 1.65 & 0.16 & 1.18 & 2 & Statistics Indonesia \\
\hline Education & 1.70 & 0.08 & 1.44 & 1.85 & Statistics Indonesia \\
\hline Health & 1.47 & 0.09 & 1.18 & 1.79 & Statistics Indonesia \\
\hline
\end{tabular}

\subsection{Model Specifications}

Based on theoretical propositions, to analyze interdependencies between monetary, macro, social and income inequality variables, has been considered a complete system of seemingly unrelated regressions (SUR) for panel data with a simultaneous model. This study is used as an appropriate estimator, with four equations included in the system. In the first equation, the monetary variables is determined by external factors as an exogenous variables and macroeconomic variables of the second equation also income inequality of the fourth equationIn equation two, macroeconomic variables influenced not only by exogenous variables but also by monetary as an endogenous explanatory variables of the first equation and social variables of the third equation also by income inequality of the fourth equation. The third equation is the social variables influenced by exogenous variables and by endogenous covariates are monetary variables of the first equation, macroeconomic of the second equation and income inequality of the fourth equation. The fourth equation is income inequality influenced by exogenous variables and by endogenous covariates that monetary variables , macroeconomic and social variables. Thus, this study system is determined as follows:

$$
\begin{aligned}
& Y_{1, i t}^{k}=\alpha_{1}+\beta_{1} \sum_{k=1}^{k} X_{1, i t}^{k}+\alpha_{12} \sum_{k=1}^{k} Y_{2, i t-1}^{k}+\alpha_{14} \sum_{k=1}^{k} Y_{4, i t-1}+u_{1, i t} \\
& Y_{2, i t}^{k}=\alpha_{2}+\alpha_{21} \sum_{k=1}^{k} Y_{1, i t-1}^{k}+\beta_{2} \sum_{k=1}^{k} X_{2, i t}^{k}+\alpha_{23} \sum_{k=1}^{k} Y_{3, i t-1}^{k}+ \\
& \alpha_{24} \sum_{k=1}^{k} Y_{4, i t-1}+u_{2, i t} \\
& Y_{3, i t}^{k}=\alpha_{3}+\alpha_{31} \sum_{k=1}^{k} Y_{1, i t-1}^{k}+\alpha_{32} \sum_{k=1}^{k} Y_{2, i t-1}^{k}+\beta_{3} \sum_{k=1}^{k} X_{3, i t}^{k}+ \\
& \quad \alpha_{34} \sum_{k=1}^{k} Y_{4, i t-1}+u_{4, i t} \\
& Y_{4, i t}=\alpha_{4}+\alpha_{41} \sum_{k=1}^{k} Y_{1, i t-1}^{k}+\alpha_{42} \sum_{k=1}^{k} Y_{2, i t-1}^{k}+\alpha_{43} \sum_{k=1}^{k} Y_{3, i t-1}^{k}+ \\
& \beta_{4} \sum_{k=1}^{k} X_{4, i t}^{k}+u_{4, i t}
\end{aligned}
$$


Jurnal Ekonomi Pembangunan: Kajian Masalah Ekonomi dan Pembangunan, 21 (2), 2020, 134-160

Where: is a constant term, "is a provincial unit \& time trend, stands for exogenous regression coefficient vector, and " is a random error term, and is a one-period lag. The variables in the first equation are inflation and credit, this variables are a monetary variables () which are determined by the exogenous variables that are; consumption, savings, wages and unemployment. are a gross regional domestic product and government expenditure. Exogenous variables are consumption, savings, and wages, unemployment, also urbensation, education and health. Variable in equation three () are population and human development index (). Exogenous variables () are health, education, and wages, unemployment, also urbensation, consumption and savings. Variable in the fourth equation ) are income inequality which is Gini index. Exogenous variables are consumption, savings, and wages, unemployment, also urbanization, education and health.

The main advantage of this system of equations is it allows considering empirical interdependencies between variables. In the SUR model, it assumes that disturbances from different regression equations, at a certain point in time, correlate because of general factors that cannot be observed (Muinelo-Gallo and RocaSagalés 2013). In this context, and compared to the single equation approach, the SUR model utilizes the efficiency gains that come from the assumed interdependence of the error terms of the four equations. The SUR model is suitable for formulating four regression equations simultaneously and the errors in these equations are correlated. The model can be assumed using ordinary least squares (OLS). Such assumptions are consistent but are generally not as efficient as the SUR method, which is equivalent to the proper least squares with specific variancecovariance matrices. The seemingly unrelated regressions (SUR) are exactly equivalent to OLS if the actual error rate does not correlate between equations (Khan, Khan et al. 2014). Therefore, in this study it is assumed to use three-stage least squares (3SLS) is an IV-GLS estimator that achieves consistency through instrumentation and efficiency through appropriate weighting.

\section{Results and Discussion}

This section presents empirical results from the specifications of different models using a sample of 33 provinces for the period 20052018. Table 2 summarizes the system results by considering Seemingly Unrelated Regression (SUR). The results are stable, indicating that no single provincial unit in the sample is driving the results. Table 2 presents the results SUR estimation for the relationship between monetary, macroeconomic, social and income inequality, with the treatment used to clear the endogeneity of the regression and increase the efficiency of the estimate. Policy implications stemming from strong results can thus be trusted as discussed below. Different regressions are determined to avoid high multicollinearity among explanatory variables. The Adj. R-squared in all models shows that all models match the data for system estimation.

\subsection{Determination of monetary variables}

Table 2. reports the results regarding the factors that determine monetary variables. When discussing monetary determinants, the first focus on macroeconomic variables. As the results show, GDP and government spending are positively related to inflation, thus showing inflation is caused by fiscal expansion in public spending and an increase in the budget for public consumption, as Nguyen (2019) found that government spending has a positive impact on inflation in Indonesia. At the same time, GDP can also increase bank credit by boosting national income and domestic savings, while government spending has a significant negative impact on bank credit. The increase in government spending raises interest rates, thereby reducing demand for bank credit, as explained by Murphy and Walsh 
Jurnal Ekonomi Pembangunan: Kajian Masalah Ekonomi dan Pembangunan, 21 (2), 2020, 134-160

(2018), Miranda-Pinto, Murphy et al. (2020) and Auerbach, Gorodnichenko et al. (2020), which supports the idea that government spending tightens credit markets. Second, the effect of income inequality was strong and positive on bank credit, and not significant on inflation. These results are as considered Stockhammer (2015) and Malinen (2016), which shows that higher income inequality leads to higher bank credit.

Other variables that jointly determine monetary variables, as the results show, consumption has a significant positive direct effect on inflation and credit. Then, the savings have a significant negative effect on inflation, while savings have a positive effect on credit, and the results also show a significant negative minimum wage effect on inflation and credit. Also found that unemployment had a significant negative effect on inflation and not significantly on credit, this result is consistent with economic theory. Then found that the growth of urbanization had a negative and direct influence on inflation and had no direct effect on credit.

\subsection{Determination of macroeconomic}

Macroeconomic equations appear in Table 2 , showing the results regarding macroeconomic determination. The first, monetary variables are the beginning to enter the regression with a significant positivecoefficient on the gross domestic product, indicating that inflation and credit drive gross domestic product. This means that inflation has a positive effect on economic growth because it increases incentives to expand production as found by Aydın, Esen et al. (2016). Credit plays an important role in Indonesia's economic growth, where credit increases production capacity by investing funds borrowed in production projects, the results are in line with those obtained by Tinoco-Zermeno, et al. (2014). While it is found that credit can determine government spending with a significant positive coefficient. This means that the government wants to revive economic energy by injecting credit with more government funds. While finding as expected inflation does not determine government spending directly and significantly.

Tabel 2. Regression results of the SUR model

\begin{tabular}{|c|c|c|c|c|c|c|c|}
\hline & \multicolumn{2}{|c|}{ Moneter Equation } & \multicolumn{2}{|c|}{ Makro Equation } & \multicolumn{2}{|c|}{ Social Equation } & \multirow{2}{*}{$\begin{array}{c}\begin{array}{c}\text { Inequality } \\
\text { Equation }\end{array} \\
\text { Gini Index }\end{array}$} \\
\hline & Inflation & Credit & $\begin{array}{c}\text { Gross } \\
\text { domestic } \\
\text { product }\end{array}$ & $\begin{array}{l}\text { Government } \\
\text { Expenditure }\end{array}$ & $\begin{array}{l}\text { Population } \\
\text { growth }\end{array}$ & $\begin{array}{c}\text { Human } \\
\text { Development }\end{array}$ & \\
\hline Inflation & - & - & $\begin{array}{l}0.4714^{*} \\
(0.0475)\end{array}$ & $\begin{array}{l}-0.0969 \\
(0.0756)\end{array}$ & $\begin{array}{l}-0.0576 \\
(0.1316)\end{array}$ & $\begin{array}{l}-0.0083 * \\
(0.0027)\end{array}$ & $\begin{array}{l}0.0433 * \\
(0.0072)\end{array}$ \\
\hline Credit & - & - & $\begin{array}{l}1.0737 * \\
(0.0570)\end{array}$ & $\begin{array}{l}0.3504 * \\
(0.0896)\end{array}$ & $\begin{array}{l}0.9800 * \\
(0.1572)\end{array}$ & $\begin{array}{l}0.0233 * \\
(0.0033)\end{array}$ & $\begin{array}{l}0.1237 * \\
(0.0089)\end{array}$ \\
\hline $\begin{array}{l}\text { Gross domestic } \\
\text { product }\end{array}$ & $\begin{array}{l}0.2512^{*} \\
(0.0397)\end{array}$ & $\begin{array}{l}0.5417 * \\
(0.0309)\end{array}$ & - & - & $\begin{array}{l}0.4750^{*} \\
(0.1248)\end{array}$ & $\begin{array}{l}0.0149 * \\
(0.0026)\end{array}$ & $\begin{array}{l}0.0642 * \\
(0.0072)\end{array}$ \\
\hline $\begin{array}{l}\text { Government } \\
\text { Expenditures }\end{array}$ & $\begin{array}{l}0.1835^{*} \\
(0.0354)\end{array}$ & $\begin{array}{l}-0.0760 * \\
(0.0268)\end{array}$ & - & - & $\begin{array}{l}0.1875 * * \\
(0.0914)\end{array}$ & $\begin{array}{l}0.0035^{* * * * *} \\
(0.0019)\end{array}$ & $\begin{array}{l}-0.0196 * \\
(0.0053)\end{array}$ \\
\hline $\begin{array}{l}\text { Population } \\
\text { growth }\end{array}$ & - & - & $\begin{array}{l}0.0952 * \\
(0.0175)\end{array}$ & $\begin{array}{l}0.1162 * \\
(0.0288)\end{array}$ & - & - & $\begin{array}{l}-0.0027 \\
(0.0026)\end{array}$ \\
\hline $\begin{array}{l}\text { Human } \\
\text { Development }\end{array}$ & - & - & $\begin{array}{l}5.6394 * \\
(0.8231)\end{array}$ & $\begin{array}{l}-6.2606^{*} \\
(1.3480)\end{array}$ & - & - & $\begin{array}{l}-1.0470 * \\
(0.1217)\end{array}$ \\
\hline $\begin{array}{l}\text { Income } \\
\text { Inequality }\end{array}$ & $\begin{array}{l}0.3195^{* *} \\
(0.2894)\end{array}$ & $\begin{array}{l}-2.9057 * \\
(0.2327)\end{array}$ & $\begin{array}{l}2.8694 * \\
(0.3494)\end{array}$ & $\begin{array}{l}-0.3542 \\
(0.5009)\end{array}$ & $\begin{array}{l}-0.0473 \\
(0.8187)\end{array}$ & $\begin{array}{l}-0.1527 * \\
(0.0169)\end{array}$ & - \\
\hline Consumption & $\begin{array}{l}0.0544 * * \\
(0.0273)\end{array}$ & $\begin{array}{l}0.0588 * \\
(0.0227)\end{array}$ & $\begin{array}{l}0.9369 * * \\
(0.0327)\end{array}$ & $\begin{array}{c}0.0682 \\
(0.0466)\end{array}$ & $\begin{array}{l}-0.5147 * \\
(0.0724)\end{array}$ & $\begin{array}{l}-0.0047 * \\
(0.0015)\end{array}$ & $\begin{array}{l}0.0050 * \\
(0.0044)\end{array}$ \\
\hline Savings & $\begin{array}{l}-0.0205 \\
(0.0427)\end{array}$ & $\begin{array}{l}0.4316^{*} \\
(0.0335)\end{array}$ & $\begin{array}{l}0.1855^{*} \\
(0.0527)\end{array}$ & $\begin{array}{l}0.5863^{*} \\
(0.0801)\end{array}$ & $\begin{array}{l}0.6550 * \\
(0.1421)\end{array}$ & $\begin{array}{l}-0.0015 \\
(0.0030)\end{array}$ & $\begin{array}{l}-0.0585^{*} \\
(0.0082)\end{array}$ \\
\hline
\end{tabular}


Avalaible online at http://journals.ums.ac.id, Permalink/DOI: 10.23917/jep.v21i2.11254

Jurnal Ekonomi Pembangunan: Kajian Masalah Ekonomi dan Pembangunan, 21 (2), 2020, 134-160

\begin{tabular}{|c|c|c|c|c|c|c|c|}
\hline & \multicolumn{2}{|c|}{ Moneter Equation } & \multicolumn{2}{|c|}{ Makro Equation } & \multicolumn{2}{|c|}{ Social Equation } & \multirow{2}{*}{$\begin{array}{c}\begin{array}{c}\text { Inequality } \\
\text { Equation }\end{array} \\
\text { Gini Index }\end{array}$} \\
\hline & Inflation & Credit & $\begin{array}{c}\text { Gross } \\
\text { domestic } \\
\text { product }\end{array}$ & $\begin{array}{l}\text { Government } \\
\text { Expenditure }\end{array}$ & $\begin{array}{l}\text { Population } \\
\text { growth }\end{array}$ & $\begin{array}{c}\text { Human } \\
\text { Development }\end{array}$ & \\
\hline $\begin{array}{l}\text { Minimum } \\
\text { wage }\end{array}$ & $\begin{array}{l}-0.1687 * \\
(0.0650)\end{array}$ & $\begin{array}{l}-0.2900 * \\
(0.0540)\end{array}$ & $\begin{array}{l}0.6979 * \\
(0.0761)\end{array}$ & $\begin{array}{c}0.1634 \\
(0.1089)\end{array}$ & $\begin{array}{l}-1.6168 * \\
(0.1735)\end{array}$ & $\begin{array}{l}0.0224 * \\
(0.0036)\end{array}$ & $\begin{array}{l}-0.0492^{*} \\
(0.0110)\end{array}$ \\
\hline $\begin{array}{l}\text { Unemployment } \\
\text { Rate }\end{array}$ & $\begin{array}{l}-0.2750 * \\
(0.1133)\end{array}$ & $\begin{array}{l}-0.1355 \\
(0.0937)\end{array}$ & $\begin{array}{l}-0.6361 * \\
(0.1236)\end{array}$ & $\begin{array}{l}1.1693^{*} \\
(0.1737)\end{array}$ & $\begin{array}{l}-0.9224 * \\
(0.2983)\end{array}$ & $\begin{array}{l}-0.0215 * \\
(0.0063)\end{array}$ & $\begin{array}{l}0.0555 * \\
(0.0173)\end{array}$ \\
\hline $\begin{array}{l}\text { Urbanization } \\
\text { Growth }\end{array}$ & $\begin{array}{l}-0.5630 * \\
(0.1265)\end{array}$ & $\begin{array}{l}-0.0797 \\
(0.1031)\end{array}$ & $\begin{array}{c}0.1331 \\
(0.1287)\end{array}$ & $\begin{array}{l}-1.8101 * \\
(0.1822)\end{array}$ & $\begin{array}{l}-0.0080 \\
(0.3431)\end{array}$ & $\begin{array}{l}0.0198^{*} \\
(0.0072)\end{array}$ & $\begin{array}{l}0.0715^{*} \\
(0.0200)\end{array}$ \\
\hline Education & - & - & $\begin{array}{l}0.8310 * \\
(0.1910)\end{array}$ & $\begin{array}{l}1.1390 * \\
(0.3060)\end{array}$ & $\begin{array}{l}-0.3630 \\
(0.4831)\end{array}$ & $\begin{array}{l}0.0840 * \\
(0.0102)\end{array}$ & $\begin{array}{c}0.0310 \\
(0.0286)\end{array}$ \\
\hline Health & - & - & $\begin{array}{l}-0.3520 * \\
(0.1383)\end{array}$ & $\begin{array}{l}-0.2536 \\
(0.2209)\end{array}$ & $\begin{array}{l}-0.7998 * * \\
(0.3743)\end{array}$ & $\begin{array}{c}0.0065 \\
(0.0079)\end{array}$ & $\begin{array}{l}0.0871 * \\
(0.0202)\end{array}$ \\
\hline Adj. R-squared & 0.79 & 0.93 & 0.91 & 0.85 & 0.86 & 0.67 & 0.33 \\
\hline
\end{tabular}

Note: Standard errors are in parentheses. ${ }^{*}, * *, * * *$ shows the statistical significance at each level $1 \%, 5 \%$, and $10 \%$.

Second, social variables, population growth and human development index, have a significant positive sign on the gross domestic product, indicating that in Indonesia population growth and human development index are variables that are relevant and affect economic growth. This means that more population means providing population in the form of human capital, this result as is produced by the Galor and Weil (1998) model which links population growth with investment in human capital to positive economic growth. This fact is consistent with the results of the Miri and Maddah (2018), which found that the effect of population growth on economic growth was positive and significant, and according to the results of Ulas and Keskin (2017) which showed that there was a positive correlation between the human development index and economic growth. Then at the same time, the population growth and human development index directly and significantly influence government spending. Population growth is positively related to government spending, meaning that the more the population increases the more needed for government expenditure increases. And also as predicted by Barro (1991), the human development index is negatively related to government spending. This means that the increases in human development will decrease the desire of the government for human development. Third, income inequality can reduce economic growth. It was found that income inequality was directly affected negatively on gross domestic product. That is in accordance with Qin, Cagas et al. (2009) which claim that the way that inequality develops has negative consequences for economic growth. These results are also in line with an empirical study conducted by Rodionov, Kudryavtseva et al. (2018) who found that a high Gini index had a negative impact on gross regional products. Then, as not expected, income inequality is directly insignificantly affected by government spending. This means that high income inequality does not affect the demand for redistribution of income by government spending.

Fourth, in relation to other variables that can determine macroeconomic, it is found a significant positive sign in the case of domestic saving, consumption, minimum wage and education on gross domestic product. Then found a significant negative sign in the case of unemployment and poor health in gross domestic product. While in the case of the variable urbanization growth has a significant negative impact on government spending, and not significantly from the urbanization growth on gross domestic product. The results show that increasing consumption and domestic savings can promote output, 
according to Gashe (2017), Patra, Murthy et al. (2017), and Gu and Tam (2013), which shows that consumption and saving encourage real activity and output growth.

The resultsindicate that high minimum wages and low unemployment contribute to economic growth, and the phenomenon of unemployment and low wages increases government spending for the purpose of overcoming the problem. This is in line with Carter (1998) and Askenazy (2003), who consider that the minimum wage that increases employment will increase output, because the minimum wage shifts efforts from production to research and development, thus accelerating economic growth, and in line with the results of Abraham and Nosa (2018) and Adelowokan, Maku et al. (2019), which found a negative relationship between the unemployment rate and the level of output growth, and also the results in accordance with Pissarides (1983) and Ono (2017) who also found that government expenditure was positively correlated with minimum wage rates and low unemployment.

The education and health increase demand for human resources thereby increasing the quality of work and production. These results are in accordance with Aslan, Menegaki et al. (2016), Sharma (2018), Ghiasi, Sarlak et al. (2019) and Neofytidou and Fountas (2020), which found that indicators of human health and education had a significant positive effect on economic growth. Then it was found as unexpected, urbanization did not have an effect on economic growth, this result was in line with the results obtained by Narayan (2016) and Potts (2016), which found that urbanization did not have a causal effect on economic growth. Then the results show that the growth of urbanization can affect government spending, as considered by Ubogue (1983), that the rate of urbanization causes high costs per capita for government goods and services.

\subsection{Determination of social variables}

In the social equation in Table 2 which presents the results of social-economic determination, the first monetary variable, as expected, the effect of inflation on population growth is not significant, but its negative and significant effect on the human development index. Meaning that high inflation also lowers the index of human development, because the rising prices for basic services and commodities reduce the level of people's welfare. This result goes with the results of Hassan, Khalid et al. (2016) which shows that inflation increases the human development index. Whereas found population growth and human development index can be determined by credit with a significant positive coefficient. Increased credit will motivate families to have children thereby increases population growth, and increases human development, according to the results of Lochner and MongeNaranjo (2012), Heckman and Mosso (2014) and Hai and Heckman (2017), which have provided evidence that credit affects human development.

Second, macroeconomic variables, the gross domestic product and government spending have significant positive signs on population growth and human development index, thereby indicating that these macro variables are relevant variables and affect population growth and human development index. As expected that macroeconomics increases the level of human development, the increasing economic growth and government spending will increase the level of human welfare, in a sense, government spending in Indonesia focuses on investment in human resources. These findings are not far from what Olofin (2020) found. Then the results that found macroeconomic positively affect population growth are not in accordance with what is considered Nelson (1956), but these results run with Sufiyan, Jummai et al. (2020) which was found when economic growth advanced, the population also increased.

Third, incomeinequality, as expected, is found income inequality has a significant positive effect on population growth and negatively influence on human development index. Meaning that income inequality increases population growth because low-income segments are more likely to choose quantity to have children than quality. This result 
Jurnal Ekonomi Pembangunan: Kajian Masalah Ekonomi dan Pembangunan, 21 (2), 2020, 134-160

is in accordance with Leibenstein (1963) who considered that the benefits of additional children are decreasing when family income rises, so lowincome families want to have more children. Then that increasing income inequality lowers the human development index, causes low levels of population welfare and worsens education and health levels, these results are in line with the results of Yang and Qiu (2016) and Thiel (2016).

Fourth, in relation to other variables that determine social variables, a significant negative sign was found in the case of consumption, minimum wage, unemployment and poor health to population growth. Indicating that an increase in consumption, minimum wage, unemployment and poor health reduced population growth. Then found a significant positive sign from savings on population growth. While as unexpected in the case of urbanization and education variables, these variables do not have a significant impact on population growth. Also, the findings show that minimum wage, urbanization and education can be increasing human development, while the consumption and unemployment decreasing human development. However, the savings and poor health variables do not have a significant sign directly on the human development index.

\subsection{Determination of income inequality}

The income inequality equation in Table 2 shows the results of determining income inequality. The first monetary variables are significant and have the expected sign, which basically coincides with Albanesi (2007), Cysne, Maldonado et al. (2005), and Gonzales and RojasHosse (2019), who are considered that inflation and income inequality are positively related, and low-income families are more susceptible to inflation because low-income households more consumption. Then as pointed out by Johansson and Wang (2014) and Ghossoub and Reed (2017), there is a positive relationship between credit pressure and income inequality. Thus, the increase in credit inequality will decrease, but at high inflation, income inequality will be higher. This result is in line with the results of Taresh
A, Sari et al. (2020), which found that credit can reduce income inequality in Indonesia while inflation increasing it.

The second, macroeconomic variables, the gross domestic product has a significant positive sign on income inequality but government spending has a negative sign, indicating that government spending is a variable that reduces income inequality, by focusing government spending on subsidies and increasing the income of the poor, and raising human development and raising living standards. This fact agrees with Akinyemi, Magareth et al. (2019) and Baker, Hone et al. (2019), which is assumed that government spending will reduce income inequality if government spending aims to increase access to quality health facilities and educational opportunities by increasing employment creation opportunities. However, the economic growth not reduced income inequality, it is not in accordance with what was given by Nguyen, Le et al. (2020) which shows that income inequality decreases with an increase in economic growth. This means that economic growth in Indonesia cannot achieve benefits for all people so that it can increase income inequality, this is in accordance with what was found by Rubin and Segal (2015). Therefore, to equitable distribute the benefits of economic growth should be promoted more equitable tax and transfer systems, and implementation of labour market reforms aimed at reducing earning gaps and unemployment or the reduction of constraints to the access of credit markets (Panjawa and Samudro 2020).

Third, regarding social variables, the human development index has a significant positive sign on income inequality, while population growth has no significant effect on income inequality. Thus, an increase in the human development index can reduce income inequality. Meaning that the level of human development brings prosperity and social justice by increasing the level of income of the poor thereby reducing income inequality in Indonesia, this result supports the evidence provided by Castells $\square$ Quintana, Royuela et al. (2019), that there is a negative relationship 
between human development and income inequality. Accordingly, a rise in the human development index increases the productivity level of the population which in turn encourages income levels to be higher (Panjawa, Samudro et al. 2018).

Fourth, in relation to other variables that determine income inequality variables, significant positive signs were found in the case of consumption, unemployment, urbanization growth, and poor health, thus these variables increase income inequality. That is, an increase in consumption, especially non-food consumption, increases income inequality, because most of the non-food consumption expenditure comes from low income goes to people with high income. And also as found by Cysne and Turchick (2012) that an increase in unemployment increases income inequality. And the results run with the results of Sulemana, Nketiah-Amponsah et al. (2019)and Qiu and Zhao (2019) who found that urbanization exacerbated income inequality. Also to be in accordance with Pickett and Wilkinson (2015) and Detollenaere, Desmarest et al. (2018) who found that poor health and the spread of disease increase income inequality.

Then the results show a significant negative sign in the case of the variable domestic savings and minimum wages, which shows that the variable reduces income inequality. While in the case of the education variable it has no significant direct impact on income inequality. This means that savings can promote income inequality, this result goes with what was found by $\mathrm{Gu}$ and Tam (2013) and Gu, Tam et al. (2018), who found that income inequality was positively influenced by savings. Also the results according to Brito and Kerstenetzky (2019) who have proven that increasing minimum wage levels reduces income inequality.

\section{Conclusions}

This study found that monetary variables namely inflation and credit jointly determined macro variables (economic growth and government spending), at the same time can determine social variables (human development and population growth), and income inequality. Secondly, it is found that macroeconomic variables are positively related to monetary variables, except in terms of government expenditure negatively related to credit, then at the same time macroeconomic is a relevant variable and positively influences social variables, and reduces income inequality in terms of government expenditure, but from the economic growth side, can increase income inequality. Third, social variables have an impact on macroeconomic variables, population growth has a positive impact on economic growth and government expenditure, and then the human development has a positive impact on the economic growth while having a negative impact on government spending, at the same time it can reduce income inequality by the human development. Fourth, the variables of consumption, savings and minimum wages, unemployment, and urbanization growth can be considered as jointly determining variables for monetary, macroeconomic, social and income inequality variables. Then the health and education variables found are the variables that jointly determine for macroeconomic, social and income inequality variables.

These results are possible to obtain policy implications that are useful for dealing with the Indonesian economy that is experiencing problems with income inequality. First, to address income inequality more quickly, the Indonesian government needs to impose redistribution of national income by advancing the role of human development and government spending, as well as setting low levels of consumption and inflation, and increasing minimum wages and public health, while at the same time reducing unemployment. Second, to improve human development, it is necessary to direct government spending and credit for investment in human resources, especially education and health. Thirdly, to achieve stable and equitable economic growth it is necessary to reduce high inflation, then to reduce inflation and increase credit it is necessary to increase production and savings, by substantially 
Jurnal Ekonomi Pembangunan: Kajian Masalah Ekonomi dan Pembangunan, 21 (2), 2020, 134-160

improving the welfare of the community.

Finally, when establishing economic policies it is necessary to consider variables that jointly affect monetary, macroeconomic and social also income inequality. Like, consumption increases inflation and macroeconomic while at the same time reducing population growth, and human development, and increasing income inequality. Savings which determine credit also pushes macroeconomics while simultaneously increasing population growth, and it can reduce income inequality. Minimum wages can reduce inflation, and encourage production growth, while reducing population growth and increasing human development, then reducing income inequality. Unemployment can also reduce inflation and increase economic growth, at the same time reducing population growth and human development while increasing income inequality. Education and health encourages economic growth and the level of human development, then can reduce income inequality.

For a more clear understanding of the monetary policies impact on the social economy and income inequality, it is recommended for future research to use national data instead of a panel so that there can be added other monetary variables, namely interest rates and the money supply.

\section{References}

Abraham, I. O. and A. L. Nosa (2018). "Unemployment and output growth: Evidence from upper-middle-income countries in Sub-Saharan Africa." American Economic \& Social Review 3(1): 32-43.

Adelowokan, O. A., et al. (2019). "Unemployment, poverty and economic growth in Nigeria." Journal of Economics \& Management 35: 5-17.

Akinbobola, T. and M. Saibu (2004). "Income inequality, unemployment, and poverty in Nigeria: a vector autoregressive approach." The Journal of Policy Reform 7(3): 175-183. Akinyemi, A., et al. (2019). "Poverty and Inequal- ity in Nigeria: Implications for Inclusive Growth.” Nile Journal of Business and Economics 4(9): 30-51.

Aksoy, C. G. (2016). "The effects of unemployment on fertility: evidence from England." The BE Journal of Economic Analysis \& Policy 16(2): 1123-1146.

Al-Marhubi, F. (1997). "A note on the link between income inequality and inflation." Economics Letters 55(3): 317-319.

Albanesi, S. (2007). "Inflation and inequality." Journal of Monetary Economics 54(4): 1088-1114.

Andersen, S. H. and B. Ozcan (2011). The effects of unemployment on fertility. European workshop on 'labour markets and demographic change'vienna/austria april (Vol. 7, p. 8).

Anghel, M.-G., et al. (2017). "The effect of unemployment on economic growth." Romanian Statistical Review Supplement 65(7): 174186.

Anisujjaman, M. (2015). "Urbanisation and human development: A study of west Bengal." International Journal of Humanities and Social Science Invention 4(7): 1-8.

Apps, P. and R. Rees (2004). "Fertility, taxation and family policy." Scandinavian Journal of Economics 106(4): 745-763.

Aremo, A. G. and S. T. Abiodun (2020). "Causal Nexus among Fiscal Policy, Economic Growth and Income Inequality in Sub-Saharan African Countries (1995-2016)." African Journal of Economic Review 8(1): 1-25.

Ashraf, Q. H., et al. (2013). "The effect of fertility reduction on economic growth." Population and development review 39(1): 97-130.

Askenazy, P. (2003). "Minimum wage, exports and growth." European Economic Review 47(1): 147-164.

Aslan, A., et al. (2016). "Health and economic growth in high-income countries revisited: 
evidence from an augmented production function for the period 1980-2009." Quality \& Quantity 50(2): 937-953.

Auerbach, A. J., et al. (2020). Effects of fiscal policy on credit markets. AEA Papers and Proceedings.

Aydın, C., et al. (2016). "Inflation and economic growth: A dynamic panel threshold analysis for Turkish Republics in transition process." Procedia-Social and Behavioral Sciences 229: 196-205.

Baker, P., et al. (2019). "Does government expenditure reduce inequalities in infant mortality rates in low-and middle-income countries?: A time-series, ecological analysis of 48 countries from 1993 to 2013." Health Economics, Policy and Law 14(2): 249-273.

Ball, L. and S. Mazumder (2019). "A Phillips Curve with Anchored Expectations and Short $\square$ Term Unemployment." Journal of Money, Credit and Banking 51(1): 111-137.

Barro, R. J. (1991). "Economic growth in a cross section of countries." The quarterly journal of economics 106(2): 407-443.

Barro, R. J. (2013). "Health and economic growth." Annals of economics and finance 14(2): 329366.

Bettencourt, L. (2020). “The Quantitative Relation between National Levels of Urbanization and Economic Growth." Mansueto Institute for Urban Innovation Research Paper Forthcoming.

Bhattacharya, B. (1998). "Urbanisation and human development in West Bengal: A district level study and comparison with inter-state variation." Economic and Political Weekly: 3027-3032.

Bhowmik, D. (2019). "Factors of human development index in ASEAN: Panel Cointegration Analysis." International Journal on Recent Trends in Business and Tourism (IJRTBT) 3(1): 8-15.
Bird, K. and C. Manning (2008). "Minimum wages and poverty in a developing country: Simulations from Indonesia's Household Survey." World Development 36(5): 916-933.

Boldrin, M. and L. E. Jones (2002). "Mortality, fertility, and saving in a Malthusian economy." Review of Economic Dynamics 5(4): 775-814.

Bölükbaş, M. (2018). "Do Inflation and Economic Growth Substantially Affect Youth Unemployment? Evidence From 20 Emerging Economies." Uluslararası İktisadi ve İdari İncelemeler Dergisi: 55-66.

Brida, J. G., et al. (2020). "Clustering and regime dynamics for economic growth and income inequality." Structural Change and Economic Dynamics 52: 99-108.

Brito, A. S. and C. L. Kerstenetzky (2019). "Has the minimum wage policy been important for reducing poverty in Brazil? A decomposition analysis for the period from 2002 to 2013." EconomiA 20(1): 27-43.

Bucci, A. and X. Raurich (2017). "Population and economic growth under different growth engines." German Economic Review 18(2): 182-211.

Budig, M. J. (2003). “Are women's employment and fertility histories interdependent? An examination of causal order using event history analysis." Social Science Research 32(3): 376-401.

Bullinger, L. R. (2017). "The effect of minimum wages on adolescent fertility: a nationwide analysis." American journal of public health 107(3): 447-452.

Cahuc, P. and P. Michel (1996). "Minimum wage unemployment and growth." European Economic Review 40(7): 1463-1482.

Cameron, D. R. (1978). "The expansion of the public economy: A comparative analysis." The American Political Science Review: 12431261. 
Carmignani, A., et al. (2019). "Urban agglomerations and firm access to credit." Bank of Italy Temi di Discussione (Working Paper) No 1222.

Carter, T. J. (1998). "Minimum wage laws: what does an employment increase imply about output and welfare?" Journal of economic behavior \& organization 36(4): 473-485.

Castells $\square$ Quintana, D., et al. (2019). "Inequality and sustainable development: Insights from an analysis of the human development index." Sustainable Development 27(3): 448-460.

Chan, K. S., et al. (2016). "Under-consumption, trade surplus, and income inequality in China." International Review of Economics \& Finance 43: 241-256.

Charles, M. and J. D. Lundy (2013). "The local Joneses: Household consumption and income inequality in large metropolitan areas." Research in Social Stratification and Mobility 34: 14-29.

Chen, D., et al. (2010). "The inequality of natural resources consumption and its relationship with the social development level based on the ecological footprint and the HDI." Journal of Environmental Assessment Policy and Management 12(01): 69-86.

Chinonso, U. E. and O. I. Justice (2016). "MODELLING NIGERIA'S URBAN AND RURAL INFLATION USING BOX-JENKINS MODEL." science 12(5): 4.

Chu, T. and Q. Wen (2017). "Can income inequality explain China's saving puzzle?” International Review of Economics \& Finance 52: 222-235.

Cooper, D., et al. (2020). "The local aggregate effects of minimum wage increases." Journal of Money, Credit and Banking 52(1): 5-35.

Cysne, R. P., et al. (2005). "Inflation and income inequality: A shopping-time approach." Journal of Development Economics 78(2): 516-528.
Cysne, R. P. and D. Turchick (2012). "Equilibrium unemployment-inequality correlation." Journal of Macroeconomics 34(2): 454-469.

Del Boca, D. and R. M. Sauer (2009). "Life cycle employment and fertility across institutional environments." European Economic Review 53(3): 274-292.

Detollenaere, J., et al. (2018). "The link between income inequality and health in Europe, adding strength dimensions of primary care to the equation." Social Science \& Medicine 201: 103-110.

Diacon, P.-E. and L.-G. Maha (2015). "The relationship between income, consumption and GDP: A time series, cross-country analysis." Procedia Economics and Finance 23: 1535-1543.

Dinopoulos, E., et al. (2018). "Effects of Credit Supply on Unemployment and Income Inequality." Federal Reserve Bank of St. Louis Review: 345-362.

Drèze, J. and M. Murthi (2001). "Fertility, education, and development: evidence from India." Population and development review 27(1): 33-63.

Dromel, N. L., et al. (2010). "Credit constraints and the persistence of unemployment." Labour Economics 17(5): 823-834.

Escudero, A. and P. Pérez Castroviejo (2010). "The living standars of miners in Biscay (1876-1936). Wages, the human development index and height." Revista de Historia Económica-Journal of Iberian and Latin American Economic History 28((3)): 503534.

Feriyanto, N. (2016). "The effect of employment, economic growth, and investment on HDI: In provinces in Indonesia." Journal of Economics, Business, and Accountancy Ventura 19(01): 1-12.

Flückiger, M. and M. Ludwig (2017). "Urbanization, fertility and child education in Sub-Saharan Africa." Economics Letters 
157: 97-102.

Gabriel, S. A. and S. S. Rosenthal (2013). "Urbanization, agglomeration economies, and access to mortgage credit.” Regional Science and Urban Economics 43(1): 42-50.

Galor, O. and D. N. Weil (1998). Population, Technology, and Growth: From the Malthusian Regime to the Demographic Transition and Beyond, National Bureau of Economic Research.

Gashe, L. (2017). "Inter-play between saving, inflation and economic growth in Ethiopia: linkages and threshold analysis." Global J Hum Soc Sci 17(4): 46-54.

Ghiasi, M., et al. (2019). "Effect of health capital on the economic growth process of Iranian provinces using generalized method of moments approach." Journal of Research and Health 9(1): 21-28.

Ghosh, S. (2020). "Impact of economic growth volatility on income inequality: ASEAN experience." Quality \& Quantity: 1-44.

Ghossoub, E. A. and R. R. Reed (2017). "Financial development, income inequality, and the redistributive effects of monetary policy." Journal of Development Economics 126: 167-189.

Gnègnè, Y. (2009). "Adjusted net saving and welfare change." Ecological Economics 68(4): 1127-1139.

Goldstone, J. A. (1984). "Urbanization and inflation: lessons from the English price revolution of the sixteenth and seventeenth centuries." American Journal of Sociology 89(5): 1122-1160.

Gonzales, R. and A. Rojas-Hosse (2019). "Inflation shocks and income inequality." African Journal of Economic and Management Studies 10(2): 226-240.

$\mathrm{Gu}, \mathrm{X}$. and P. S. Tam (2013). "The saving-growthinequality triangle in China." Economic Modelling 33: 850-857.
Gu, X., et al. (2018). "An alternative explanation for high saving in China: Rising inequality." International Review of Economics \& Finance.

Gumata, N. and E. Ndou (2017). Does Government Spending Transmit Inflation to GDP Growth? Labour Market and Fiscal Policy Adjustments to Shocks, Springer: 461-466.

Haan, P. and K. Wrohlich (2011). "Can child care policy encourage employment and fertility?: Evidence from a structural model." Labour Economics 18(4): 498-512.

Hai, R. and J. J. Heckman (2017). "Inequality in human capital and endogenous credit constraints." Review of Economic Dynamics 25: 4-36.

Han, S. and C. B. Mulligan (2008). "Inflation and the Size of Government." REVIEW-FEDERAL RESERVE BANK OF SAINT LOUIS 90(3): 245.

Hassan, M. U., et al. (2016). "Evaluating the dilemma of inflation, poverty and unemployment." Bulletin of Business and Economics (BBE) 5(2): 67-82.

Heckman, J. J. and S. Mosso (2014). "The economics of human development and social mobility." Annu. Rev. Econ. 6(1): 689-733.

Johansson, A. C. and X. Wang (2014). "Financial sector policies and income inequality." China Economic Review 31: 367-378.

Jones, C. I. (1997). Population and ideas: A theory of endogenous growth, National Bureau of Economic Research.

Jones, C. I. (2020). The End of Economic Growth? Unintended Consequences of a Declining Population, National Bureau of Economic Research.

Karra, M., et al. (2017). "The effect of fertility decline on economic growth in Africa: A macrosimulation model." Population and development review 43: 237-263.

Khan, M. A., et al. (2014). "Global estimates of 
energy-growth nexus: Application of seemingly unrelated regressions." Renewable and Sustainable Energy Reviews 29: 63-71.

Khan, N. and M. Naushad (2020). "Inflation Relationship With the Economic Growth of the World Economy." Available at SSRN 3542729 .

Koh, S. G., et al. (2020). "The income inequality, financial depth and economic growth nexus in China." The World Economy 43(2): 412427.

Kreyenfeld, M. and G. Andersson (2013). "Socioeconomic differences in the unemployment and fertility nexus: A comparison of Denmark and Germany." Max Planck Institute for Demographic Research Working Paper WP 8.

Kuznets, S. (1955). "Economic growth and income inequality." The American economic review 45(1): 1-28.

Lee, M. R. (2001). "Population growth, economic inequality, and homicide." Deviant Behavior 22(6): 491-516.

Leibenstein, H. (1963). Population Growth and the Take-Off Hypothesis. The Economics of Take-Off into Sustained Growth, Springer: 170-184.

Li, H. and H.-f. Zou (2002). "Inflation, growth, and income distribution: A cross-country study." Annals of economics and finance 3(1): 85-101.

Lise, J., et al. (2014). "Wage, income and consumption inequality in Japan, 1981-2008: From boom to lost decades." Review of Economic Dynamics 17(4): 582-612.

Lochner, L. and A. Monge-Naranjo (2002). Human capital formation with endogenous credit constraints, National Bureau of Economic Research.

Lochner, L. and A. Monge-Naranjo (2012). "Credit constraints in education." Annu. Rev. Econ. 4(1): 225-256.
Lucas Jr, R. E. (1988). "On the mechanics of economic development." Journal of Monetary Economics 22(1): 3-42.

Lutz, W. and S. K. KC (2013). "Demography and human development: Education and population projections." UNDP-HDRO Occasional Papers(2013/04).

Lutz, W. and K. Samir (2011). "Global human capital: Integrating education and population." science 333(6042): 587-592.

Mahajan, N. (2020). "Role of higher education in economic development (special reference of private university in lucknow district)." Journal of Business Management \& Quality Assurance (e ISSN 2456-9291) 3(2): 4348.

Malinen, T. (2016). "Does income inequality contribute to credit cycles?" The Journal of Economic Inequality 14(3): 309-325.

Marks, G. N. (2015). "Education and Income Distribution." International Encyclopedia of the Social \& Behavioral Sciences(Second Edition): Pages 132-136.

Matchaya, G., et al. (2018). "Income growth, population and savings in the Southern Africa Development Community region." South African Journal of Economic and Management Sciences 21(1): 1-9.

Mehrara, M., et al. (2016). "The impact of government spending on inflation through the inflationary environment, STR approach." World Scientific News 37: 153-167.

Miranda-Pinto, J., et al. (2020). "Saving constraints, debt, and the credit market response to fiscal stimulus: Theory and Cross-Country Evidence.”.

Miri, N. and M. Maddah (2018). The effect of age structure of the population on economic growth in Iran using the ARDL approach. AIP Conference Proceedings, AIP Publishing LLC.

Muinelo-Gallo, L. and O. Roca-Sagalés (2013). 
"Joint determinants of fiscal policy, income inequality and economic growth." Economic Modelling 30: 814-824.

Murphy, D. and K. J. Walsh (2018). "Government spending and interest rates." Review of Economic Dynamics 18((3)): 551-574.

Nagayasu, J. (2017). "Inflation and consumption of nontradable goods: Global implications from regional analyses." International Review of Economics \& Finance 48: 478-491.

Narayan, L. (2016). "Relationship between urbanisation and economic growth: a causality analysis for India." Indian Journal of Economics and Development 12(2): 237-242.

Nelson, R. R. (1956). "A theory of the low-level equilibrium trap in underdeveloped economies." The American economic review 46(5): 894-908.

Neofytidou, A. and S. Fountas (2020). "The impact of health on GDP: A panel data investigation." The Journal of Economic Asymmetries 21: e00139.

Neumark, D. (2019). "The Higher Wages Tax Credit." Expanding Economic Opportunity for More Americans." Melissa S. Kearney and Amy Ganz, eds.(Aspen, CO: The Aspen Institute Economic Strategy Group): 196212.

Neumayer, E. (2001). "The human development index and sustainability - a constructive proposal.” Ecological Economics 39(1): 101114.

Nguyen, H., et al. (2020). "The linkages between growth, poverty and inequality in Vietnam: An empirical analysis." Accounting 6(2): 177-184.

Nguyen, T. D. (2019). "Impact of Government Spending on Inflation in Asian Emerging Economies: Evidence from India, China, and Indonesia." The Singapore Economic Review 64(05): 1171-1200.

Olofin, O. P. (2020). "Human Development, Gov- ernment Spending and Economic Growth in West Africa." Asian Research Journal of Arts \& Social Sciences: 30-36.

Ono, T. (2017). "Growth, Unemployment, and Fiscal Policy: A Political Economy Analysis." Graduate School of Economics and Osaka School of International Public Policy (OSIPP) Osaka University Discussion Papers In Economics And Business 14: 1-51.

Panjawa, J. L. and B. R. Samudro (2020). "Spatial Redistributions of Regional Economic Activity in Central Java (Direct Error Correction Model Causality Approach).” Jurnal Ekonomi Pembangunan: Kajian Masalah Ekonomi dan Pembangunan 21(1): 1-13.

Panjawa, J. L., et al. (2018). "Regional Economic Disparities in Eastren Indonesia and Determinants: Comparative Analysis of Origin District and New District." Regional Science Inquiry 10(1): 117-124.

Patra, S. K., et al. (2017). "Revisiting the causal nexus between savings and economic growth in India: An empirical analysis." EconomiA 18(3): 380-391.

Peia, O. and K. Roszbach (2015). "Finance and growth: time series evidence on causality." Journal of Financial Stability 19: 105-118.

Pickett, K. E. and R. G. Wilkinson (2015). "Income inequality and health: a causal review." Social Science \& Medicine 128: 316-326.

Pissarides, C. A. (1983). "Efficiency aspects of the financing of unemployment insurance and other government expenditure." The Review of Economic Studies 50(1): 57-69.

Potts, D. (2016). "Debates about A frican urbanisation, migration and economic growth: what can we learn from $\mathrm{Z}$ imbabwe and $\mathrm{Z}$ ambia?" The Geographical Journal 182(3): 251-264.

Puhakka, M. and M. Viren (2012). "SOCIAL SECURITY, SAVING AND FERTILITY." Finnish Economic Papers 25(1). 
Jurnal Ekonomi Pembangunan: Kajian Masalah Ekonomi dan Pembangunan, 21 (2), 2020, 134-160

Qin, D., et al. (2009). "Effects of income inequality on China's economic growth." Journal of Policy Modeling 31(1): 69-86.

Qiu, L. and D. Zhao (2019). "Urban inclusiveness and income inequality in China." Regional Science and Urban Economics 74: 57-64.

Razmi, M. J., et al. (2012). Investigating the effect of government health expenditure on HDI in Iran. Journal of Knowledge Management, KMRP: 1-13.

Rodionov, D. G., et al. (2018). "Human development and income inequality as factors of regional economic growth."

Romer, P. M. (1986). "Increasing returns and long-run growth." Journal of political economy 94(5): 1002-1037.

Rubin, A. and D. Segal (2015). "The effects of economic growth on income inequality in the US." Journal of Macroeconomics 45: 258273.

Saputri, R. F. and N. Woyanti (2014). Analisis Pengaruh Investasi Sumber Daya Manusia Terhadap Pertumbuhan Ekonomi di Jawa Tengah, Fakultas Ekonomika dan Bisnis.

Sarker, S., et al. (2016). "Urban population and economic growth: South Asia perspective." European Journal of Government and Economics 5(1): 64-75.

Sengupta, A. and A. Ghosha (2008). "Urbanisation and human welfare in the era of globalisation: A case study in Buedwan, West Bengal.” Artha Vijnana L(2): 129-150.

Sharma, R. (2018). "Health and economic growth: Evidence from dynamic panel data of 143 years." PloS one 13(10): e0204940.

Shonchoy, A. S. (2010). "Determinants of government consumption expenditure in developing countries: A panel data analysis." Institute of Developing Economies Discussion Paper, (266).

Siddique, M. A. B., et al. (2014). Fiscal decentralisation and inequality in Indonesia: 1999-
2008, University of Western Australia, Business School, Economics.

Sinding, S. W. (2009). "Population, poverty and economic development." Philosophical Transactions of the Royal Society B: Biological Sciences 364(1532): 3023-3030.

Stockhammer, E. (2015). "Rising inequality as a cause of the present crisis." Cambridge Journal of Economics 39(3): 935-958.

Sufiyan, I., et al. (2020). "Spatial-Temporal Variation as An Effective Socio-Economic Impact of Population Growth in Mararaban Guruku, Nasarawa State Nigeria." Acta Scientifica Malaysia (ASM) 4(1): 04-08.

Suleiman, S. H., et al. (2017). "Unemployment and Economic Growth in Tanzania." Journal of Economics, Management and Trade: $1-8$.

Sulemana, I., et al. (2019). "Urbanization and income inequality in Sub-Saharan Africa." Sustainable Cities and Society 48: 101544.

Tanninen, H. (1999). "Income inequality, government expenditures and growth.” Applied Economics 31(9): 1109-1117.

Taresh A, A., et al. (2020). "Analysis of The Relationship among Macroeconomics, Monetary and Income Inequality." Economics Development Analysis Journal 9(4): 427-442.

Taye, A. Y. (2017). "The saving-inflation puzzle: explaining their relationship in Ethiopia." IOSR J. Humanities Social Sci.(IOSRJHSS 22 (2), 74-81.

Thiel, F. (2016). "The Effect of Inequality on (Human) Development-Insights from a Panel Analysis of the Human Development Index."

Tinoco-Zermeno, M. A., et al. (2014). "Growth, bank credit, and inflation in Mexico: evidence from an ARDL-bounds testing approach." Latin American Economic Review 23(1): 8 .

Tripathi, S. (2019). "Urbanization and Human 
Development Index: Cross-country evidence.” Munich Personal RePEc Archive, pp. 97474 .

Ubogue, R. E. (1983). "Urbanisation, fiscal decentralisation and economic development: A time series evidence." Socio-Economic Planning Sciences 17(4): 191-198.

Ulas, E. and B. Keskin (2017). Is There a Relation Between HDI and Economic Performances? New trends in finance and accounting, Springer: 61-70.

Van Wijnbergen, S. (1983). "Credit policy, inflation and growth in a financially repressed economy." Journal of Development Economics 13(1-2): 45-65.

Varvarigos, D. and P. Arsenis (2015). "Corruption, fertility, and human capital." Journal of economic behavior \& organization 109: 145-162.

Widodo, P., et al. (2019). "Government Spending on Education, Health, and Minimum Wages as Predictors of Human Development Index: Study of Selected Provinces of Indonesia." International Journal of Advanced Economics 1(2): 95-101.

Yang, J. and M. Qiu (2016). "The impact of education on income inequality and intergenerational mobility." China Economic Review 37: 110-125.

Yolanda, Y. (2017). "Analysis of factors affecting inflation and its impact on human development index and poverty in Indonesia." European Research Studies Journal 20(4B): 38-56. 